University of Nebraska - Lincoln

DigitalCommons@University of Nebraska - Lincoln

$1-10-2020$

\title{
Microalgae as a promising and sustainable nutrition source for managed honey bees
}

Vincent A. Ricigliano

USDA-ARS, Baton Rouge, Vincent.ricigliano@usda.gov

Follow this and additional works at: https://digitalcommons.unl.edu/usdaarsfacpub

Ricigliano, Vincent A., "Microalgae as a promising and sustainable nutrition source for managed honey bees" (2020). Publications from USDA-ARS / UNL Faculty. 2313.

https://digitalcommons.unl.edu/usdaarsfacpub/2313

This Article is brought to you for free and open access by the U.S. Department of Agriculture: Agricultural Research Service, Lincoln, Nebraska at DigitalCommons@University of Nebraska - Lincoln. It has been accepted for inclusion in Publications from USDA-ARS / UNL Faculty by an authorized administrator of DigitalCommons@University of Nebraska - Lincoln. 


\title{
Microalgae as a promising and sustainable nutrition source for managed honey bees
}

\author{
Vincent A. Ricigliano
}

Honey Bee Breeding, Genetics and Physiology Research, USDA-ARS, Baton Rouge, Louisiana

\section{Correspondence}

Vincent A. Ricigliano, Honey Bee Breeding, Genetics and Physiology Research, USDA-ARS, Baton Rouge, LA 70820.

Email: Vincent.Ricigliano@USDA.gov

\begin{abstract}
Managed honey bee colony losses are attributed to a number of interacting stressors, but many lines of evidence point to malnutrition as a primary factor. Commercial beekeepers have become increasingly reliant on artificial pollen substitute diets to nourish colonies during periods of forage scarcity and to bolster colony size before pollination services. These artificial diets may be deficient in essential macronutrients (proteins, lipids, prebiotic fibers), micronutrients (vitamins, minerals), and antioxidants. Therefore, improving the efficacy of pollen substitutes can be considered vital to modern beekeeping. Microalgae are prolific sources of plant-based nutrition with many species exhibiting biochemical profiles that are comparable to natural pollen. This emerging feed source has been employed in a variety of organisms, including limited applications in honey bees. Herein, I introduce the nutritional value and functional properties of microalgae, extrapolating to central aspects of honey bee physiology and health. To conclude, I discuss the potential of microalgae-based feeds to sustainably provision managed colonies on an agricultural scale.
\end{abstract}

\section{KEYWORDS}

antioxidant, apis mellifera, microbiota, pollen substitute, prebiotic

\section{1 | INTRODUCTION}

Nutritional status is among the most important modifiable determinants of honey bee health. In honey bees, malnutrition interacts with and amplifies the detrimental effects of parasites, pathogens, and pesticide exposure (Dolezal \& Toth, 2018; Dolezal et al., 2019; Tosi, Nieh, Sgolastra, Cabbri, \& Medrzycki, 2017). Pollen is the colony's main source of proteins, lipids, vitamins and minerals (Brodschneider \& Crailsheim, 2010). As such, beekeepers 
have become increasingly reliant on feeding artificial pollen substitute (PS) diets as landscape compositions shift to agriculturally intensive monocultures that do not meet the nutritional requirements of bees (Donkersley, Rhodes, Pickup, Jones, \& Wilson, 2014; Ricigliano et al., 2018).

PS diets used by beekeepers typically contain soy, yeast, egg, wheat, or lentils in an effort to provide essential nutrition and sustain colony growth during forage dearth or poor landscape conditions (Standifer, 1980). Soy flour is a common PS ingredient despite containing putative anti-nutritional factors, such as protease inhibitors (Sagili, Pankiw, \& Zhu-Salzman, 2005) and toxic sugars (Barker, 1977). Early PS formulations failed to match the nutritional efficacy of pollen and had low palatability (Standifer, Haydak, Mills, \& Levin, 1973), whereas current commercial PSs have not been robustly tested. The development of novel PSs for honey bees should aim to reproduce the nutrition profile and functional characteristics of pollen in a sustainable formulation.

Microalgae, which are mostly photosynthetic unicellular microorganisms, have gained traction for their use as a nutrition source for insects (Qiu, Wang, Xiao, \& Ge, 2019), aquaculture (Guedes, Sousa-Pinto, \& Malcata, 2015), livestock (Madeira et al., 2017), and humans (Caporgno \& Mathys, 2018). The phytochemical profile of microalgae closely resembles pollen (Figure 1), making it an attractive feed source to supplement honey bee nutrition. Rapid growth rates and biomass production of microalgae enables them to surpass current protein feed resources (such as soy) on an area basis using nonarable land, lessening some environmental burdens of modern agriculture (Lamminen, Halmemies-Beauchet-Filleau, Kokkonen, Jaakkola, \& Vanhatalo, 2019; Tallentire, Mackenzie, \& Kyriazakis, 2018). This review introduces the nutritional value and functional properties of microalgae, extrapolating to central aspects of honey bee nutritional physiology, and concludes by discussing the potential of microalgae to sustainably provision honey bee colonies on an agricultural scale.

\section{2 | PROTEINS}

The nutritional composition of microalgae is generally well characterized. A significant body of nutritional and toxicological research indicates that microalgal biomass can be used as a single protein source or feed additive in a variety of organisms (Caporgno \& Mathys, 2018; Guedes et al., 2015; Madeira et al., 2017). The most promising genera relevant to livestock diets are Arthrospira and Chlorella. Arthrospira (commonly called spirulina) are blue-green microalgae that contain between $60 \%$ and $70 \%$ protein dry weight. Arthrospira proteins are highly

\section{Macronutrients}

Essential amino acids (De Groot 1953)(Guedes et al. 2015; Lamminen et al. 2019) Essential lipids (Manning 2001; Wegener et al. 2018)(Ryckebosch et al. 2014; Xue et al. 2018)

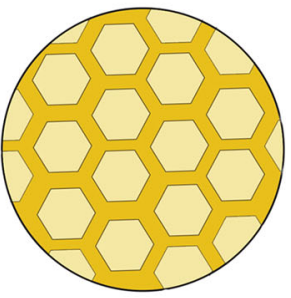

Pollen

\section{Micronutrients \\ Vitamins and minerals \\ (Standifer 1980) \\ (Fábregas \& Herrero 1986; Brown et al. 1999) \\ Antioxidants \\ (Leja et al. 2007)(Li et al. 2007; Goiris et al. 2012) \\ Prebiotics}

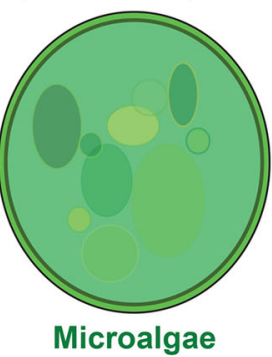

Microalgae

(Kešnerová et al. 2017; Ricigliano et al. 2017) (Parada et al. 1998; de Jesus Raposo et al. 2015; Moreno et al. 2017)

FIGURE 1 Biochemical similarities between pollen (orange text) and microalgae (green text), highlighting nutritional and functional properties that are relevant to honey bee health 
bioavailable and provide all essential amino acids (EAAs), which are present in almost half its total protein content (Soni, Sudhakar, \& Rana, 2017). Chlorella are green microalgae that contain 50-60\% protein dry weight and a full complement of EAAs (Kotrbáček, Doubek, \& Doucha, 2015). The EAAs required by honey bees are arginine, histidine, isoleucine, leucine, lysine, methionine, phenylalanine, threonine, tryptophan, and valine (De Groot, 1953), all of which must be obtained from pollen. When nurse bees consume pollen, amino acids are incorporated into the fat body storage lipoprotein vitellogenin, which acts as a precursor to proteinaceous hypopharyngeal gland secretions (jelly) used to rear brood (Crailsheim, 1990). The microalga Chlorella sorokiniana was recently shown to positively impact honey bee colony growth and individual nutritional physiology (fat body protein content, vitellogenin messenger RNA levels, and hypopharyngeal gland size), indicating that Chlorella is promising as a PS or diet additive (Jehlík et al., 2019). In one study, Arthrospira was incorporated into a PS formulation that led to improved colony performance compared to unfed control colonies (Kumar, Mishra, \& Agrawal, 2013), however the effects of Arthrospira on fine-scale aspects of individual bee and colony-level health have yet to be characterized.

\section{3 | LIPIDS}

While significant research and commercial efforts have been made to match the protein and amino acid contents of pollen, there has been comparatively less focus on the lipid content of PS diets (Ghosh \& Jung, 2015; Manning, 2001). Pollen contains a broad diversity of lipids (reviewed in Ischebeck, 2016), that are highly variable depending on plant species (Chakrabarti, Morré, Lucas, Maier, \& Sagili, 2019). Microalgae are renowned for their lipid content as it relates to biofuel applications but are also recognized as a rich source of nutritionally relevant lipids, including polyunsaturated fatty acids (PUFAs; Xue et al., 2018) (Ryckebosch et al., 2014). Linoleic and $\alpha$-linoleic acids are two PUFAs that are essential for honey bees (Arien, Dag, Zarchin, Masci, \& Shafir, 2015). Further, dietary PUFA content is correlated with fat body vitellogenin (vg) expression (Wegener, Jakop, Schiller, \& Müller, 2018). Chlorella sorokiniana has lipid contents of 10-20\% dry weight and was shown to increase fat deposition in honey bees (Jehlík et al., 2019). However, other spieces possess even higher lipid contents (dry weight), such as Botryococcus (25-75\%), Nanochloropsis (31-68\%), and Schizochytrium (50-77\%; Demirbas \& Demirbas, 2011)

\section{4 | MICRONUTRIENTS}

Micronutrients, which include vitamins and minerals, are as important as macronutrients (Gupta, Kening, \& Liang, 2008) but have been mostly overlooked in the context of honey bee nutrition. Honey bees obtain micronutrients from pollen as well as "dirty" or turbid water (Butler, 1940). Analysis of bee-collected pollen revealed seasonal fluctuations in mineral levels of potassium, calcium, magnesium and sodium (Bonoan et al., 2017). Algae may also be collected by bees to supplement macronutrition and micronutrition, although this has not been demonstrated beyond anecdotal observations that bees will interact with algae at turbid water sources (Figure 2). Nevertheless, microalgae represent a valuable source of vitamins (tocopherols, ascorbic acid, B vitamins) and minerals (sodium, potassium, calcium, and magnesium; Fabregas \& Herrero, 1990).

\section{5 | ANTIOXIDANTS}

Nectar and pollen are the honey bee's dietary sources of antioxidants. The antioxidant properties of pollen are attributed to its phenolic content, which may ameliorate cellular damage incurred by oxidative stress. Microalgae are rich in antioxidants, including phenolics (Li et al., 2007) and various photosynthetic pigments including 


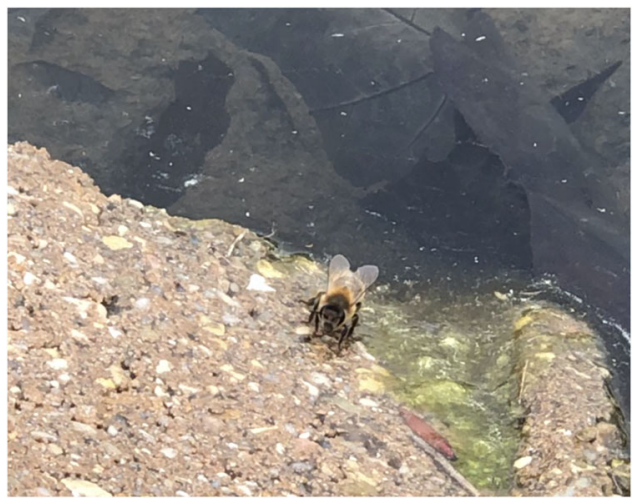

FIGURE 2 Honey bee at a turbid water source featuring algae at the ground-water interface

carotenoids (Goiris et al., 2012). The microalgal carotenoid astaxanthin is well-studied for its potent antioxidant and immunomodulating properties (Higuera-Ciapara, Felix-Valenzuela, \& Goycoolea, 2006). Currently, the main source of microalgal astaxanthin is Haematococcus pluvialis, but additional species are under investigation for the production of astaxanthin and related carotenoids (Ambati, Phang, Ravi, \& Aswathanarayana, 2014).

\section{I PREBIOTIC AND FUNCTIONAL POLYSACCHARIDES}

Honey bee guts are populated by a microbial consortium, or microbiota, that is the subject of significant research interest due to its implications in health and disease (Raymann \& Moran, 2018). Evidence has emerged demonstrating the beneficial effects of some diet ingredients and bioactive compounds on animal hosts or gut microbiota beyond their primary nutritional roles. Among these "functional ingredients," the polysaccharides are a promising group (Xu, Xu, Ma, Tang, \& Zhang, 2013). This includes dietary fibers, which are broadly defined as non-digestible carbohydrates and lignins found in plants. Some dietary fibers are prebiotic, meaning they may be fermented by the gut microbiota, conferring a broad range of physiological benefits to the host animal (Slavin, 2013). Microalgae exhibit a wide variety of polysaccharide-rich extracellular matrices, which are involved in various physiological processes and environmental interactions (Xiao \& Zheng, 2016). Indeed, microalgae have recently been identified as an emergent source of prebiotics with potential to modulate the microbiome, and consequently alter the trajectory of various disease states (de Jesus Raposo, De Morais, \& De Morais, 2015). Structurally similar to pollen, microalgal extracellular matricies incorporate cellulose, hemicelluloses (xyloglucan, mannans, glucuronan, $\beta$-glucans), and pectin-like carbohydrates (Xiao \& Zheng, 2016). In honey bees, indigestible pollen fibers act as fermentation substrates for the core gut microbiota groups Lactobacillus, Bifidobacterium, and Gilliamella (Kešnerová et al., 2017). The major fermentative products produced by the bee microbiota are organic acids, which influence bee metabolism, behavior, (Zheng, Powell, Steele, Dietrich, \& Moran, 2017) and immune function (Kwong, Mancenido, \& Moran, 2017). In vitro and in vivo models indicate that microalgal biomass can stimulate the abundance and metabolism of Lactobacillus, a ubiquitous group of beneficial lactic acid bacteria that are core to many insect and vertebrate microbiota (de Jesus Raposo et al., 2015; Moreno, Corzo, Montilla, Villamiel, \& Olano, 2017; Parada, de Caire, de Mulé, \& de Cano, 1998). Since bee-associated bacterial symbionts co-evolved with a pollen diet, the gut microbiome phenotype could be a useful metric to evaluate the non-nutritive effects of artificial diets on bee physiology (Ricigliano et al., 2017). Intriguingly, a sulphated polysaccharide from the microalga Porphyridium was shown to impact honey bee gut health through a non-prebiotic mechanism (Roussel et al., 2015). In this study, feeding the isolated polysaccharide led to decreased parasite load and bee mortality due to 
infection by the gut parasite Nosema cerane, possibly via disruption of Nosema adhesion to the gut epithelium. Taken together, the incorporation of microalgal biomass into bee diets has potential for diet-based microbiota manipulations to improve disease resistance.

\section{7 | CONCLUSION AND FUTURE PERSPECTIVE}

Malnutrition is increasingly recognized as a major stress factor underlying managed honey bee colony mortality throughout the United States and across the world (López-Uribe, Ricigliano, \& Simone-Finstrom, 2020). As a result, there are multiple ongoing efforts to improve bee nutrition. One approach focuses on improving the quality of floral resources through supplemental plantings and landscape enrichment that could augment pollinator nutrition (Decourtye, Mader, \& Desneux, 2010). While still early in its implementation, there are limited reports demonstrating a significant impact of supplemental plantings on commercially managed honey bees whereas semi-natural conservation habitats appear to have a stronger positive influence on bee health (Alaux et al., 2017; Ricigliano et al., 2019). Taking into consideration the ecological impacts of climate change and a growing human population, feeding honey bees and other livestock should not compete for arable land that could otherwise be dedicated to conservation efforts or human food production (Draaisma et al., 2013; Lamminen et al., 2019). Intensively cultivated landscapes may not provide the floral diversity necessary for optimal bee nutrition (Donkersley et al., 2014). Microalgae represent an alternative approach to the growing problem of malnutrition, with many species possessing all of the EAAs and lipids required by bees. Similar to current PSs employed by beekeepers, microalgae patties can be applied inside bee hives, above the brood nest (Figure 3). This method is optimal for efficiently feeding the thousands of commercially managed colonies that are involved in agricultural pollination. Microalgae cultivation is highly efficient, done without pesticides or antibiotics and requires minimal water inputs compared to terrestrial plant protein feed resources (Lamminen et al., 2019). Adapting beekeeping and broader livestock management practices with microalgae feeds could contribute to achieving objectives outlined in the United Nations sustainable development goals (SDGs; https://sustainabledevelopment.un.org/sdgs) related to food security (SDG 2), sustainable water management (SDG 6), sustainable consumption (SDG 12), climate change (SDG 13), reversal of land degradation, and halting biodiversity loss (SDG 15). In order for this goal to be realized, in depth characterization of the effects of different microalgae species on bee physiology and health are necessary.

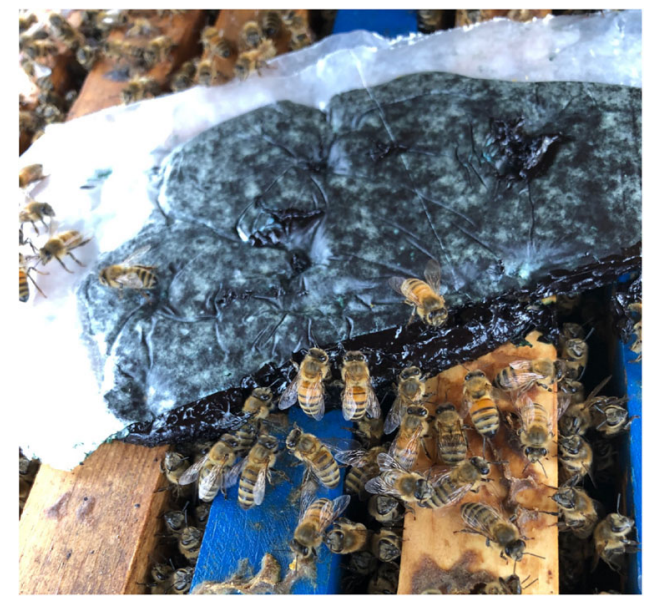

FIGURE 3 Delivery of a pollen substitute patty containing Arthrospira (spirulina) biomass to a honey bee colony 


\section{ACKNOWLEDGMENTS}

I thank the members of the USDA-ARS Honey Bee Breeding, Genetics, and Physiology lab for cultivating a positive work environment and for their stimulating discussions.

\section{CONFLICT OF INTERESTS}

The authors declare that there are no conflict of interests.

\section{ORCID}

Vincent A. Ricigliano (D) http://orcid.org/0000-0002-5167-5812

\section{REFERENCES}

Alaux, C., Allier, F., Decourtye, A., Odoux, J. F., Tamic, T., Chabirand, M., ... Henry, M. (2017). A 'Landscape physiology' approach for assessing bee health highlights the benefits of floral landscape enrichment and semi-natural habitats. Scientific Reports, 7, 40568.

Ambati, R. R., Phang, S. M., Ravi, S., \& Aswathanarayana, R. G. (2014). Astaxanthin: Sources, extraction, stability, biological activities and its commercial applications-A review. Marine Drugs, 12(1), 128-152.

Arien, Y., Dag, A., Zarchin, S., Masci, T., \& Shafir, S. (2015). Omega-3 deficiency impairs honey bee learning. Proceedings of the National Academy of Sciences, 112(51), 15761-15766.

Barker, R. J. (1977). Some carbohydrates found in pollen and pollen substitutes are toxic to honey bees. The Journal of Nutrition, 107(10), 1859-1862.

Bonoan, R. E., Tai, T. M., Rodriguez, M. T., Feller, L., Daddario, S. R., Czaja, R. A., ... Starks, P. T. (2017). Seasonality of salt foraging in honey bees (Apis mellifera). Ecological Entomology, 42(2), 195-201.

Brodschneider, R., \& Crailsheim, K. (2010). Nutrition and health in honey bees. Apidologie, 41(3), 278-294.

Butler, G. C. (1940). The choice of drinking water by the honey bee. Journal of Evolutionary Biology, 27, 253-261.

Caporgno, M. P., \& Mathys, A. (2018). Trends in microalgae incorporation into innovative food products with potential health benefits. Frontiers in Nutrition, 5(58), https://doi.org/10.3389/fnut.2018.00058

Chakrabarti, P., Morré, J. T., Lucas, H. M., Maier, C. S., \& Sagili, R. R. (2019). The omics approach to bee nutritional landscape. Metabolomics, 15(10), 127.

Crailsheim, K. (1990). The protein balance of the honey bee worker. Apidologie, 21(5), 417-429.

Decourtye, A., Mader, E., \& Desneux, N. (2010). Landscape enhancement of floral resources for honey bees in agroecosystems. Apidologie, 41(3), 264-277.

Demirbas, A., \& Demirbas, M. F. (2011). Importance of algae oil as a source of biodiesel. Energy Conversion and Management, 52(1), 163-170.

Dolezal, A. G., Carrillo-Tripp, J., Judd, T. M., Allen Miller, W., Bonning, B. C., \& Toth, A. L. (2019). Interacting stressors matter: Diet quality and virus infection in honeybee health. Royal Society Open Science, 6(2), 181803.

Dolezal, A. G., \& Toth, A. L. (2018). Feedbacks between nutrition and disease in honey bee health. Current Opinion in Insect Science, 26, 114-119.

Donkersley, P., Rhodes, G., Pickup, R. W., Jones, K. C., \& Wilson, K. (2014). Honeybee nutrition is linked to landscape composition. Ecology and Evolution, 4(21), 4195-4206.

Draaisma, R. B., Wijffels, R. H., Slegers, P. E., Brentner, L. B., Roy, A., \& Barbosa, M. J. (2013). Food commodities from microalgae. Current Opinion in Biotechnology, 24(2), 169-177.

Fabregas, J., \& Herrero, C. (1990). Vitamin content of four marine microalgae. Potential use as source of vitamins in nutrition. Journal of Industrial Microbiology, 5(4), 259-263.

Ghosh, S., \& Jung, C. (2015). Nutritional evaluation of four commercially available pollen patties in Korea. Journal of Apiculture, 30(3), 155-160.

Goiris, K., Muylaert, K., Fraeye, I., Foubert, I., De Brabanter, J., \& De Cooman, L. (2012). Antioxidant potential of microalgae in relation to their phenolic and carotenoid content. Journal of Applied Phycology, 24(6), 1477-1486.

De Groot, A. P. (1953). Protein and amino acid requirements of the honeybee (Apis mellifica L.). Physiologia Comparata et Oecologia, 3, 1-83. 
Guedes, A. C., Sousa-Pinto, I., \& Malcata, F. X. (2015). Application of microalgae protein to aquafeed, Handbook of Marine Microalgae (pp. 93-125). Academic Press.

Gupta, U. C., Kening, W. U., \& Liang, S. (2008). Micronutrients in soils, crops, and livestock. Earth Science Frontiers, 15(5), 110-125.

Higuera-Ciapara, I., Felix-Valenzuela, L., \& Goycoolea, F. M. (2006). Astaxanthin: A review of its chemistry and applications. Critical Reviews in Food Science and Nutrition, 46(2), 185-196.

Ischebeck, T. (2016). Lipids in pollen-They are different. Biochimica et Biophysica Acta (BBA)-Molecular and Cell Biology of Lipids, 1861(9), 1315-1328.

Jehlík, T., Kodrík, D., Krištůfek, V., Koubová, J., Sábová, M., Danihlík, J., ... Frydrychová, R. Č. (2019). Effects of Chlorella sp. on biological characteristics of the honey bee Apis mellifera. Apidologie, 50(4), 564-577.

de Jesus Raposo, M. F., De Morais, A. M. B., \& De Morais, R. M. S. C. (2015). Marine polysaccharides from algae with potential biomedical applications. Marine Drugs, 13(5), 2967-3028.

Kešnerová, L., Mars, R. A., Ellegaard, K. M., Troilo, M., Sauer, U., \& Engel, P. (2017). Disentangling metabolic functions of bacteria in the honey bee gut. PLoS Biology, 15(12), e2003467.

Kotrbáček, V., Doubek, J., \& Doucha, J. (2015). The chlorococcalean alga Chlorella in animal nutrition: A review. Journal of Applied Phycology, 27(6), 2173-2180.

Kumar, R., Mishra, R. C., \& Agrawal, O. P. (2013). Effect of feeding artificial diets to honey bees during dearth period under Panchkula (Haryana) conditions. Journal of Entomological Research, 37, 41-46.

Kwong, W. K., Mancenido, A. L., \& Moran, N. A. (2017). Immune system stimulation by the native gut microbiota of honey bees. Royal Society Open Science, 4(2), 170003.

Lamminen, M., Halmemies-Beauchet-Filleau, A., Kokkonen, T., Jaakkola, S., \& Vanhatalo, A. (2019). Different microalgae species as a substitutive protein feed for soya bean meal in grass silage based dairy cow diets. Animal Feed Science and Technology, 247, 112-126.

Li, H. B., Cheng, K. W., Wong, C. C., Fan, K. W., Chen, F., \& Jiang, Y. (2007). Evaluation of antioxidant capacity and total phenolic content of different fractions of selected microalgae. Food Chemistry, 102(3), 771-776.

López-Uribe, M. M., Ricigliano, V. A., \& Simone-Finstrom, M. (2020). Defining pollinator health: A holistic approach based on ecological, genetic, and physiological factors. Annual Reviews in Animal Biosciences, 8(1), https://doi.org/10.1146/ annurev-animal-020518-115045. In Press.

Madeira, M. S., Cardoso, C., Lopes, P. A., Coelho, D., Afonso, C., Bandarra, N. M., \& Prates, J. A. (2017). Microalgae as feed ingredients for livestock production and meat quality: A review. Livestock Science, 205, 111-121.

Manning, R. (2001). Fatty acids in pollen: A review of their importance for honey bees. Bee World, 82(2), 60-75.

Moreno, F. J., Corzo, N., Montilla, A., Villamiel, M., \& Olano, A. (2017). Current state and latest advances in the concept, production and functionality of prebiotic oligosaccharides. Current Opinion in Food Science, 13, 50-55.

Parada, J. L., de Caire, G. Z., de Mulé, M. C. Z., \& de Cano, M. M. S. (1998). Lactic acid bacteria growth promoters from Spirulina platensis. International Journal of Food Microbiology, 45(3), 225-228.

Qiu, S., Wang, S., Xiao, C., \& Ge, S. (2019). Assessment of microalgae as a new feeding additive for fruit fly Drosophila melanogaster. Science of the Total Environment, 667, 455-463.

Raymann, K., \& Moran, N. A. (2018). The role of the gut microbiome in health and disease of adult honey bee workers. Current Opinion in Insect Science, 26, 97-104.

Ricigliano, V. A., Fitz, W., Copeland, D. C., Mott, B. M., Maes, P., Floyd, A. S., ... Anderson, K. E. (2017). The impact of pollen consumption on honey bee (Apis mellifera) digestive physiology and carbohydrate metabolism. Archives of Insect Biochemistry and Physiology, 96(2), e21406.

Ricigliano, V. A., Mott, B. M., Floyd, A. S., Copeland, D. C., Carroll, M. J., \& Anderson, K. E. (2018). Honey bees overwintering in a southern climate: Longitudinal effects of nutrition and queen age on colony-level molecular physiology and performance. Scientific Reports, 8(1), 10475.

Ricigliano, V. A., Mott, B. M., Maes, P. W., Floyd, A. S., Fitz, W., Copeland, D. C., ... Anderson, K. E. (2019). Honey bee colony performance and health are enhanced by apiary proximity to US Conservation Reserve Program (CRP) lands. Scientific Reports, 9(1), 4894.

Roussel, M., Villay, A., Delbac, F., Michaud, P., Laroche, C., Roriz, D., ... Diogon, M. (2015). Antimicrosporidian activity of sulphated polysaccharides from algae and their potential to control honeybee nosemosis. Carbohydrate Polymers, 133, 213-220.

Ryckebosch, E., Bruneel, C., Termote-Verhalle, R., Goiris, K., Muylaert, K., \& Foubert, I. (2014). Nutritional evaluation of microalgae oils rich in omega-3 long chain polyunsaturated fatty acids as an alternative for fish oil. Food Chemistry, 160, 393-400.

Sagili, R. R., Pankiw, T., \& Zhu-Salzman, K. (2005). Effects of soybean trypsin inhibitor on hypopharyngeal gland protein content, total midgut protease activity and survival of the honey bee (Apis mellifera L). Journal of Insect Physiology, 51(9), 953-957.

Slavin, J. (2013). Fiber and prebiotics: Mechanisms and health benefits. Nutrients, 5(4), 1417-1435. 
Soni, R. A., Sudhakar, K., \& Rana, R. S. (2017). Spirulina-From growth to nutritional product: A review. Trends in Food Science \& Technology, 69, 157-171.

Standifer, L. N. (1980). Honey bee nutrition and supplemental feeding. Beekeeping in the United States Agriculture Handbook, 335, 39-45.

Standifer, L. N., Haydak, M. H., Mills, J. P., \& Levin, M. D. (1973). Influence of pollen in artificial diets on food consumption and brood production in honey bee colonies. American Bee Journal, 113, 94-95.

Tallentire, C. W., Mackenzie, S. G., \& Kyriazakis, I. (2018). Can novel ingredients replace soybeans and reduce the environmental burdens of European livestock systems in the future? Journal of Cleaner Production, 187, 338-347.

Tosi, S., Nieh, J. C., Sgolastra, F., Cabbri, R., \& Medrzycki, P. (2017). Neonicotinoid pesticides and nutritional stress synergistically reduce survival in honey bees. Proceedings of the Royal Society B: Biological Sciences, 284(1869), 20171711.

Wegener, J., Jakop, U., Schiller, J., \& Müller, K. (2018). The membrane phospholipid composition of honeybee (Apis mellifera) workers reflects their nutrition, fertility, and vitellogenin stores. Insectes Sociaux, 65(3), 381-391.

Xiao, R., \& Zheng, Y. (2016). Overview of microalgal extracellular polymeric substances (EPS) and their applications. Biotechnology Advances, 34(7), 1225-1244.

Xu, X., Xu, P., Ma, C., Tang, J., \& Zhang, X. (2013). Gut microbiota, host health, and polysaccharides. Biotechnology Advances, 31(2), 318-337.

Xue, Z., Wan, F., Yu, W., Liu, J., Zhang, Z., \& Kou, X. (2018). Edible oil production from microalgae: A review. European Journal of Lipid Science and Technology, 120(6), 1700428.

Zheng, H., Powell, J. E., Steele, M. I., Dietrich, C., \& Moran, N. A. (2017). Honeybee gut microbiota promotes host weight gain via bacterial metabolism and hormonal signaling. Proceedings of the National Academy of Sciences, 114(18), 4775-4780.

How to cite this article: Ricigliano VA. Microalgae as a promising and sustainable nutrition source for managed honey bees. Arch. Insect Biochem. Physiol. 2020;104:e21658. https://doi.org/10.1002/arch.21658 